Simone de Beauvoir

\title{
Starost
}

Starost I: Stališče zunanjosti (2018). ISBN: 978-961-94287-71

Starost II: Biti v svetu (2020). ISBN: 978-961-94813-18

Ljubljana: Opro, zavod za aplikativne študije

Debela knjiga (661 str.) oz. esej, kot ga je poimenovala avtorica pred 50 leti (delo je v izvirniku izšlo leta 1970), opisuje odnos družbe do starih ljudi. Avtorica opiše starost in položaj, $\mathrm{v}$ katerem so bili stari ljudje diskriminirani v preteklosti in so takšni še vedno. Kljub časovni oddaljenosti izida je knjiga aktualna še danes. Avtorica vključuje antropološka pričevanja, primerjave med različnimi družbami in kulturami v preteklosti, etične in sociološke vidike ter vse to spretno povezuje z različnimi literarnimi ilustracijami in pogledi filozofije na starost. Rezultat je ena najbolj celostnih študij starosti.

Struktura besedila je jasna in pregledna - poglavja so zapisana kot sklenjena celota z vidika različnih disciplin, povezujejo pa jih položaj starega človeka, statusni boj, moč v družbi in iz tega izhajajoč odnos do starosti. Poglavja dopolnjujejo dodatek o stoletnikih, povzetek o tem, kdo se ukvarja z ostarelimi, položaj starih delavcev v socialistični družbi, na koncu pa še tema, ki je v že tako marginalizirani skupini starih potisnjena še bolj iz zaznavnega polja pravic starih ljudi v družbi - seksualnost pri starih ljudeh. Za slovenske bralce in bralke je vsekakor zanimiv del tudi o položaju delavcev v socialističnih državah. Avtorica predstavi slovensko in jugoslovansko situacijo in pokaže zelo dobro poznavanje razmer v takratni Jugoslaviji: povprečna pokojnina $v$ Jugoslaviji je znašala $72 \%$ plače, v Sloveniji pa le $62 \%$ (pozneje se je zmanjšala na $59 \%$ ), pač posledica jugoslovanske uravnilovke pokojnin.
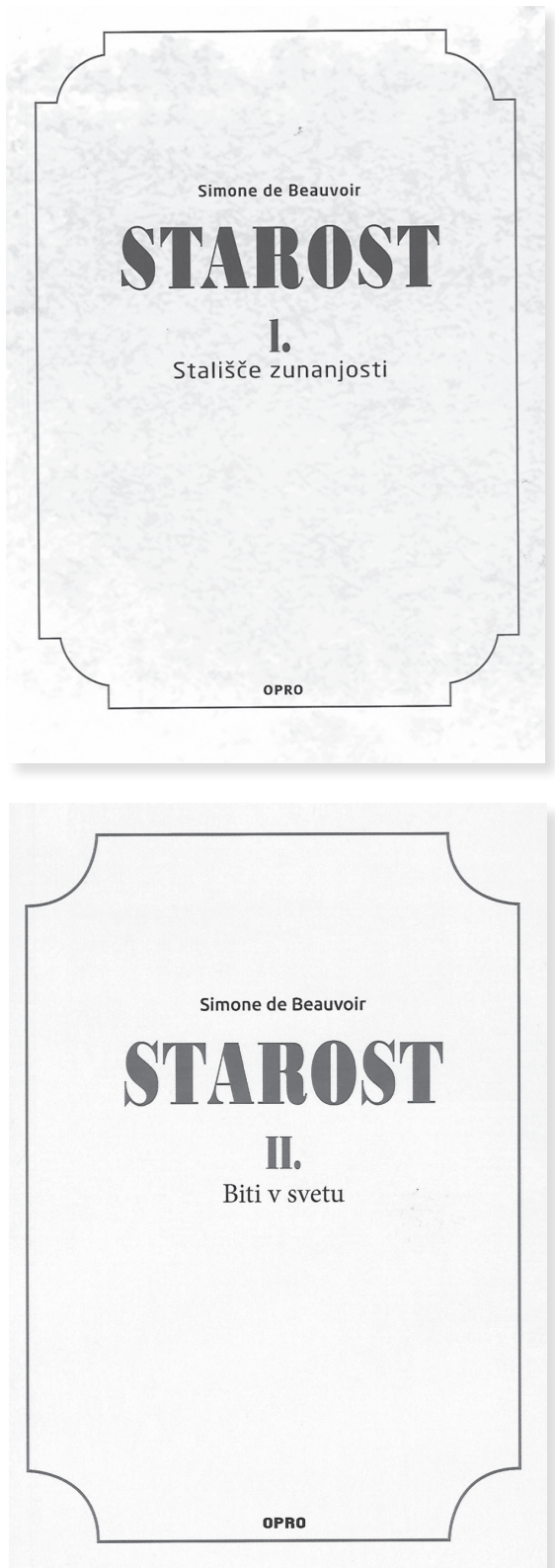
Odnos do starih ljudi je odvisen od odločanja o nas in »njih«. Kdo so »oni« in kdaj se začnemo zavedati, da smo na tej poti nezaznavno postali »oni« tudi mi? Takrat pa je že prepozno, saj drugi odločajo o nas, o naših pravicah, o tem, kaj je za nas dobro, koliko nam pripada, da ne bomo pomenili prevelikega bremena za družbo. Avtorica opozarja, da beda starosti ne izhaja sama iz sebe, temveč jo ustvarja družba - ob tem pa doda, da se prepozna kultura družbe v njenem odnosu do starih ljudi in starosti.

Vprašanje, ki se bralcu postavlja ves čas branja knjige in ga podaja tudi avtorica sama in na katero do zdaj nismo znali uspešno odgovoriti, ne da bi bilo to povezano s položajem moči in kapitala, je: kaj bi morala storiti družba, da bi človek v starosti ostal človek? Si človek le do točke, ko pomeniš prispevek za družbo? V čem smo torej naredili korak naprej od časov plemen nomadov, ko je star človek pomenil le nekoga, ki oškoduje mlade, in sta zato le dve možni rešitvi - odide sam umret $\mathrm{v}$ samoto ali pa njegovo življenje končajo z obredom - z izjemo družb, kjer so imeli redki stari ljudje zaradi svojega statusa privilegiran položaj modreca?

Avtorica je imela s knjigo o starosti namen razbiti zaroto tišine, a ji je to le delno uspelo, saj ostaja grenak priokus, da se zarota tišine - pogled na družbo, v kateri so stari ljudje »tisti nevidni stari« in je starajoča se družba le "problem« - zelo hitro spet vzpostavi. Verjetno bo šele vse več starih ljudi v družbi spremenilo družbene procese in poglede, saj 30, 40 in 50 odstotkov ljudi v družbi v naslednjih desetletjih preprosto ne bo več mogoče prezreti. Vztrajanje pri zahtevi, da bi morali ljudje v zadnjih letih življenja ostati ljudje, bi v naši družbi povzročilo prevrat - prav starost nam kaže, da je treba o vsem znova premisliti - zato vse te težave ostajajo previdno skrite v tišini, piše avtorica.

Opozarja, da je odnos družbe do starih zelo protisloven in zaznamovan z zmotnimi prepričanji, kot piše v uvodu (str. 35):

Če stari pokažejo enake želje, enaka čustva ali enake zahteve kot mladi, se ljudje nad njimi zgražajo. Zanje sta ljubezen in ljubosumnost starih ostudni ali absurdni, seksualnost odbojna in nasilnost komična. Od starih ljudi se zahteva, da so vzoren primer vseh vrlin. Predvsem pa naj bi ves čas izžarevali vedrost: kar pomeni, da taki so, vedri, kar omogoča, da si svet zatiska oči pred njihovo ne-srečo. Očiščena slika starih, ki jim jo družba ponuja, je sivolasa in častitljiva modrost, bogate izkušnje, lebdenje visoko nad običajnimi razmerami človeštva. Če se tega ne držijo, padejo pod te običajne razmere. Nasprotna stran navedene podobe je nori senilni starec, ki je $v$ posmeh otrokom.

Večina doživi starost. »Med vsemi stvarnostmi je starost morda tista, o kateri kar najdlje v svojem življenju gojimo podobo, ki je nadvse abstraktna«, avtorica navaja Prousta (str. 36). Vendar si nihče ne predstavlja sebe kot starega, dokler se ne znajde tam. Dokler ne napoči naš čas, je to nekaj, kar se dogaja drugim. Ker, ko se bo starost zgodila nam, to ne bomo več mi.

V prvem poglavju z naslovom »Starost in biologija « avtorica predstavi proces zaznavanja pešanja in staranja. Začne daleč v zgodovini - pri Hipokratu in Pitagori. Vzroke za starost so stari Grki iskali že v pradavnini in se 
že takrat zavedali dejstva, ki ga v sodobnem času pogosto pozabimo, in sicer, da je odgovor na usihanje organizma odvisen od same ideje življenja, ki ga je medicina (takrat) videla kot celoto.

Geriatrija je postala stvarnost šele v 19. stoletju. V Franciji jo je spodbudilo ustanavljanje velikanskih ustanov, $\mathrm{v}$ katerih je bilo zbranih veliko starih - največja je bila Salpêtrière, kjer so namestili osem tisoč pacientov - med njimi je bilo od dva do tri tisoč starih ljudi! Sledile so mnoge raziskave, med katerimi je imela Cazalisova teorija, da je človek star toliko, kolikor so stare njegove arterije, na začetku 20. stoletja velik uspeh. Precej pozneje se je ob geriatriji začela razvijati še druga veja znanosti - gerontologija - ki raziskuje ne samo patologijo staranja, temveč tudi proces staranja. Gerontologija se je razvijala na treh ravneh - biološki, psihološki in socialni.

Avtorica potem opiše biološke spremembe pri staranju. Raziskovalci v petdesetih letih 20. stoletja so potrdili, da kronološka in biološka starost človeka ne sovpadata vedno, saj »aktivnost dejansko zagotavlja določeno mero zdravja, tudi v starosti«. Avtorica predstavi tudi ugotovitev poročila Ameriškega inštituta za duševno zdravje, da so stari ljudje dovzetnejši za duševne bolezni kot mlajši. Danes gre starim ljudem bolje kot nekdaj, piše avtorica in navede pomenljivo misel, da je manj starih priklenjenih na postelje (nekako tako bi lahko zapisali tudi danes - grozljivo, saj pomeni, da so še vedno priklenjeni).

V drugem poglavju z naslovom »Etnološki podatki« avtorica opiše različne obrede, ki ponazarjajo, kakšen odnos so imele posamezne skupnosti do starih ljudi, kot so izgon v samoto, samomori, pokopi živih. Stari ljudje so bili odrinjeni v kote bivališč, odvisni od ostankov hrane, da niso bremenili aktivnih članov plemena. Le redki so primeri skupnosti, v katerih so stari sobivali z družino. Kot piše avtorica, imajo stari najraje, da jih pustijo dostojanstveno umreti. $V$ primitivnih skupnostih je to pomenilo umreti na samem, zapuščen v kolibi, na kajaku, ali pa jim na poti v smrt pomagajo člani družine z umorom (jih npr. zadavijo s kitovo kostjo ali vržejo z vrha gore). Primerov, da so skupnosti stare ljudi častile zaradi znanja in njihovega položaja, je avtorica našla precej manj kot primerov, da so pomenili stari ljudje grožnjo. Drugo poglavje sklene $\mathrm{z}$ mislijo, da uporabljajo tako imenovani civilizirani norci enake metode, le da je pobijanje prepovedano, če le ni dobro prikrito.

V tretjem poglavju z naslovom »Starost v zgodovinskih družbah « avtorica odnos do starosti analizira s pomočjo mitologije, legend in Homerjevega razumevanja starosti kot modrosti, ki pa ga pozneje preglasijo temnejše misli o starosti - o nemočnih, blodnjavih starcih, ki še mogočnega Herkula na starost prikažejo kot škrata. Opis odnosa družbe do starih v srednjem veku obogati s številnimi verzi od antike, ki še barviteje prikažejo odnos do starosti v tedanji družbi, ki bi jih prav zlahka preslikali tudi v odnos do starih v današnji družbi.

Avtorica navaja tudi opevan vodnjak mladosti, idejo, ki je živela v grafiki in poeziji. Kot opiše v tem poglavju, je bila starost prikazana zelo stereotipno od starega Egipta vsaj do renesanse. Odnos do starosti v družbi se je v 17. in 18. stoletju kazal v različnih gledaliških igrah, v katerih so prikazovali stare ljudi ironično in s pokroviteljskim nasmeškom. Kljub zakonskim podlagam, s katerimi so skušali stare obvarovati pred surovostjo in zanemarjanjem, je bilo stare 
ljudi pogosto videti, kako so beračili in bili vsem v nadlogo. Bolj pozitivno pa je o starosti pisal Grimm konec 19. stoletja, češ da je to čas miru in spokojnosti.

$\mathrm{V}$ četrtem poglavju z naslovom »Starost v današnjem času « de Beauvoir trdi, da je položaj starih ljudi danes škandalozen. Sprašuje se, kako si lahko zatiskamo oči pred zlorabo in nehumanim odnosom. Razvijajoč se sistem socialne varnosti ne dosega želenih ciljev, z izjemo treh držav: Švedska, Norveška in Danska. Avtorica poglavje dopolni z opisom pogojev za različne dodatke in pravice - primerjalno $\mathrm{v}$ različnih državah. S stališča socialnega dela je še zanimivejši opis nastajanja domov za stare, njihove kulture in vpliva, ki ga je imela kultura domov na stare ljudi. Avtorica opozori na problem osamljenosti. Da bi se položaj starih ljudi v resnici izboljšal, bi morali spremeniti odnos do njih in začeti načrtovati skupne politike: spodbujati način življenja, ki je tudi v starosti aktiven - tako $\mathrm{v}$ zdravstvenem kot $\mathrm{v}$ socialnem pogledu - in omogočiti dostojno starost, katere osnova je pokojnina.

V drugem delu knjige - Starost II: Biti v svetu - avtorica piše o tem, kako telesno odkrivamo in sprejemamo starost v vsakdanjem življenju.

$\mathrm{V}$ petem poglavju z naslovom »Odkrivanje in sprejemanje starosti - izkušnje telesa" se avtorica sprašuje, kdaj se počutimo stare. Ko se pogledamo v ogledalo ali nas drugi določijo za stare? Ni se preprosto odpovedati občutku, da si še vedno mlad, navaja avtorica in ob tem spretno umešča filozofski in literarni razmislek. Predstavi primere starih pisateljev, ki so si z življenjem z zmernostjo $\mathrm{v}$ vseh užitkih zagotovili zdravo in prijetno starost; podrobno opisuje tudi pot staranja, ki so jo prehodili Tolstoj, Hugo in drugi. V tem poglavju avtorica piše tudi o seksualnosti pri starih ljudeh.

V šestem poglavju z naslovom »Čas, dejavnosti, zgodovina« de Beauvoir razpravlja o spominih in njihovem pomenu, po katerem presoja posameznik svoje življenje, in piše, da v resnici z nami upravlja preteklost, tako dejanja kot dogodki iz otroštva, kamor se stari ljudje radi vračajo in o čemer radi pripovedujejo. Avtorica se ukvarja z ustvarjalnostjo starajočih se umetnikov, politikov, psihologov ... in sklene, da se, tudi če star človek ostane pri močeh in je dobrega zdravja in ga družba ni izločila iz dejavnosti, njegov svet, želje in projekti kljub temu krčijo - vse bolj tudi on spoznava, da prihaja smrt. Poglavje sklene z mislimi o smrti - zelo neposredno piše, da je v razmerah, kakršne danes družba zagotavlja večini starih ljudi, preživetje nesmiselna preizkušnja in zato po njenem mnenju tudi ne čudi, da se mnogi odločijo za skrajšanje življenja.

V sedmem poglavju z naslovom »Starost in vsakdanje življenje« piše, da starost ni čas uživanja in brezdelja. Jasno zapiše, da je to narobe, saj mora biti star človek aktiven in radoveden. Za navadami starega človeka se skriva strah, saj ga spremembe v starosti ogrožajo in mu jemljejo avtonomijo in zdravje. Postaja obrnjen v preteklost, spomini pešajo, okrog njega nastaja vse večja praznina. Avtorica navaja britanskega filozofa Powysa, ki je hvalil starost - v tem obdobju se človek lahko prepusti radostim kontemplacije in pomeni obdobje razcveta - filozof je v starosti izdal čudovite knjige. Starost posameznik lahko zato doživlja tudi kot svobodo, ko je »vse dovoljeno«, obdobje nedela - še vedno pa je njegova največja sreča, če ima še vedno veliko ciljev. Avtorica opozori tudi na številne duševne bolezni, ki so jih v 19. stoletju 
opisovali le kot senilno demenco. Pomenljiva je misel avtorice, da bi se večini motenj lahko izognili, če bi bil družbeni položaj starih manj beden. Trdi, da je demenca najpogosteje umetni proizvod pomanjkanja nege, preventivnih ukrepov in rehabilitacije.

V osmem poglavju z naslovom »Nekaj primerov starosti« opisuje, kako je lahko videti življenje starega človeka, če se lahko ukvarja s svojim poslanstvom do smrti. Probleme pešanja in obžalovanja išče tudi v mislih umetnikov, ki se niso mogli sprijazniti s starostjo: opisuje npr. Chateaubrianda in Lamartina ter njuno iskanje samega sebe v starosti in svoje podobe s pomočjo pogledov drugih, spominov in navad.

Poglavje »Sklep« avtorica začne s trditvijo, da starost ni nujno konec človekovega bivanja. Spet ponovi osnovno misel, da je lepa starost le za peščico privilegiranih, saj fizični delavec ne more skrbeti za svoje zdravje in se to pozneje kaže tudi v njegovi starosti. Bralec ne sme prezreti njenega kritičnega razmišljanja o starostni politiki družbe, ki je po njenem mnenju zločin - saj se ljudje začnejo prehitro starati zaradi odnosa družbe, ki jih sistematično uničuje v starosti. Po njenem se družba (še vedno) meni za starega človeka le toliko, kolikor ji je lahko koristen.

Delo avtorica sklene $\mathrm{z}$ dodatki: s prvim o stoletnikih, $\mathrm{v}$ drugem $\mathrm{v}$ Burgerjevem članku »Kdo se ukvarja s starimi« izvemo več o domovih za stare in negovalnih domovih (nastanitev starega človeka v dom je prikazana, kot če bi star avto zapeljali med staro železo), v tretjem dodatku pa de Beauvoir opisuje razmere za stare ljudi v socialističnih državah in podrobneje opiše primer Jugoslavije in Slovenije (posledica njenega in Sartrovega bivanja v Bohinju in zato boljšega poznavanja razmer).

Sklenem lahko, da je knjiga Starost še vedno zelo aktualno gradivo za vse, ki jih zanima področje starosti in medgeneracijskih odnosov, saj omogoča razumevanje delovanja družbe in odnosa družbe do starih ljudi. Avtorica prikaže starost iz različnih perspektiv - antropološko, sociološko, fiziološko. S poudarjanjem neverjetno podobnega odnosa do starih od antične Grčije do danes v bralcu vzbudi vtis o nesprejemanju starosti kot enakovrednega obdobja za družbo in o nesprejemanju starosti pri posamezniku (to je lahko le posledica družbenega odnosa). V marsikaterem stavku lahko prepoznamo tudi današnji odnos do starih ljudi, le da je lepše zamaskiran - dogajanje med štirimi stenami ali v domovih za stare pa je še vedno lahko podobno življenju pred 50, 100 leti. Kako to preseči? Morda šele z večjim deležem starih ljudi v družbi, ki se zares spreminja zaradi vse daljše življenjske dobe. Do cilja živeti dostojno starost - pa nas kljub temu loči še osnovni prepad med nami, ki smo družba in ustvarjamo, gradimo, in njimi - starimi.

\section{Anamarija Kejžar}


